\title{
PECULIARITIES OF FAMILY LAW IN THE CHOSON KINGDOM
}

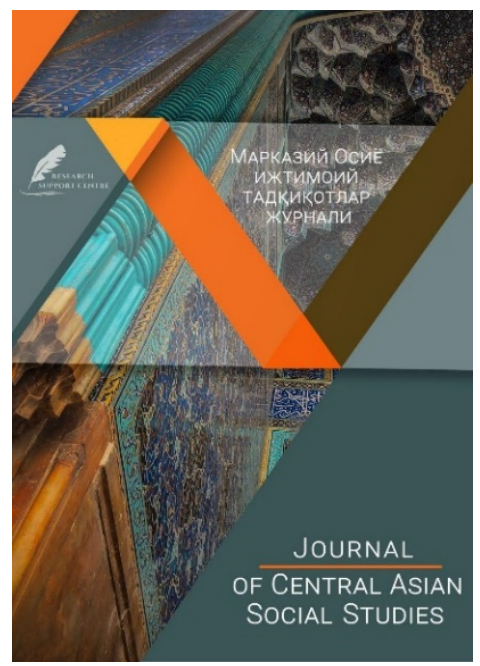

Nodira Bakhtiyor kizi Nazarkulova

MA of History,

Lecturer at the Department of Korean History, Culture, Politics and Economics,

Tashkent State University of Oriental Studies

osiyouzturk@bk.ru

\begin{abstract}
All religions have a system of rules governing the family. In Islam, family law is called odat, and women's rights are strictly protected, while in Hinduism, books describing Hindu religions such as the Arthashastra and the Dharmashastra show that there is a system of rules that encourages a woman to obey her husband in any situation. This article focuses on family law in Korea during the Choson Dynasty, examining the impact of Confucianism on family procedures and its main differences from Buddhism, as well as issues related to divorce.
\end{abstract}

Key words: neo-Confucianism, Buddhism, family law, Yi Song Gye, Kyongguk taejon, widows, chilgo chi ak, hangil, sambugǒ, pedo.

\section{CHOSON QIROLLIGIDA OILAVIY HUQUQNING O'ZIGA XOS XUSUSIYATLARI}

Annotatsiya. Barcha dinlarda oilani boshqaradigan qoidalar tizimi mavjud. Islomda oila qonunchiligi odat deb ataladi va ayollarning huquqlari qat'iy himoya qilinadi, hinduizmda esa hindu dinlarining Artashastra va Dxarmashastra dinlarini tavsiflovchi kitoblari ayolni har qanday vaziyatda eriga itoat etishga undaydigan qoidalar tizimi mavjudligini ko'rsatadi. Ushbu maqola Koreyada Choson sulolasi davrida oilaviy qonunchilikka bag'ishlangan bo'lib, Konfutsiychilikning oilaviy jarayonlarga ta'siri va uning buddizmdan asosiy farqlari hamda ajralish bilan bog'liq masalalarni o'rganib chiqadi.

Kalit so'zlar: neo-konfutsiylik, buddizm, oilaviy huquq, Yi Song Gye, Kyongguk taejon, bevalar, chilgo chi ak, hangil, sambugŏ, pedo.

\section{ОСОБЕННОСТИ СЕМЕЙНОГО ПРАВА В КОРОЛЕВСТВЕ ЧОСОН}

Аннотация. Все религии имеют систему правил, регулирующих семью. В исламе семейное право называется одат, и права женщин строго защищены, в то время как в индуизме книги, описывающие индуистские религии, такие как Артхашастра и Дхармашастра, показывают, что существует система правил, которая побуждает женщину подчиняться своему мужу в любой ситуации. Эта статья посвящена семейному праву в Корее во времена династии Чосон, исследуя влияние конфуцианства на семейные процедуры и его основные отличия от буддизма, а также вопросы, связанные с разводом. 
Ключевые слова: неоконфуцианство, буддизм, семейное право, Йи Сон Гье, Кёнгук тэджон, вдовы, чилго чи ак, хангиль, самбуго, педо.

Introduction. Various aspects of family relationships during the Chosun Dynasty have been the focus of a number of scholarly studies, and several Korean scholars, including Edward Y.J. Chung in the context of Korean Confucianism, Lim Sungyun discusses family law and the situation of widows during Japanese colonial rule (19101945), Jisoo M. Kim studied the direct appeals made by Korean women to the king himself on family and economic problems by the end of the Chosun State. While much emphasis has been placed on the role of Confucianism as an ideological guardian in the social and moral life of women, it is relatively rare for its function to regulate the family in general to be reflected in legislation. However, the neo-Confucianism takes the woman as an integral part of the family and even puts her below the family. Without research on the family, feminist and gender research, which is the most important factor in determining the status of a Korean woman in society, it would be incomprehensible.

\section{Attitudes toward the family in neo- Confucianism ${ }^{i}$ and Buddhism}

When the Yi dynasty seized power on the Korean Peninsula (1392), the legislation of the Korean dynasty was still in force, which did not suit the interests of the new dynasty. On the other hand, King Yi Son Ge (1392-1398) followed the path of changing the political ideology of the state. The newly established Confucian doctrine is not a new doctrine for the country, the sources say that this doctrine entered the Korean Peninsula in the III-IV centuries $\mathrm{AD}$ and gained respect both among the people and among the upper classes. Moreover, Confucianism is not a religion, but a complex philosophical doctrine that combines the rules of public administration and public morality [5, 53-73]. Accordingly, it does not react in any negative way to the coexistence of other religions with itself. On the other hand, even if
Confucianism is taken as a religion, Buddhism is tolerant of polytheism. For this reason, during the reign of the Choson Kingdom, and even now, the teachings of Buddhism and Confucianism have not completely disappeared, but have been satisfying the religious needs of society in mutual harmony.

The new regimes of the Yi dynasty did not completely abolish Buddhism, but reduced its political and economic opportunities. Buddhism is no longer a state ideology ${ }^{\mathrm{ii}}$. As the Yi dynasty replaced the state ideology, it reformed many of the practices that had previously been in place. The most important part of these procedures for us is related to family law and the changing status of women in society.

Ideologically, in Buddhism and Confucianism, the view of the family is radically different. For Buddhism, attaining nirvana in the process of attaining divine perfection must be the main purpose of human life; it can be concluded from this that any needs, including family issues, will be an obstacle to this goal. In the teachings of Confucius, the family has a special place and is a social institution that requires special attention as a special foundation of society. If in Buddhism all the rules of the family consist of the "Five Rules" [1, 2-4], in Confucianism the morality of the family forms a whole system of obligations and procedures. Buddhist priests intervene in family life in two main ways: the adoption of a family member into a religious sect and the mourning ceremony. All other family ceremonies and traditions are performed based on the people's own values and customs. There are no significant differences between the rights and duties of women and men in the family [2, 3-7]. However, when the new Confucianism gained the status of a state ideology, its influence became apparent in the family, along with other areas that were 
important for the unity and stability of the country.

\section{Legislation aimed at regulating the family}

In 1392, the founder of the kingdom, King Taejo (Yi Song Gye), stated that "faithful servants, good generations, wise husbands, and honorable wives are all very important for good morals and should therefore be supported" [5, 201-208]. According to the neo-Confucianism doctrine, the stability of society and the state is sustained by the establishment of a strict order within the family. At the same time, the obedience of the child to the parents and the wife to the husband was the highest value, and this order was the first link in the chain of moral relations in society. However, the responsibility for maintaining the stability of the family seems to fall more on the woman. Already, disconnected from active social and political life, it was considered the most appropriate and honorable duty for women sentenced to live in anban ${ }^{\text {iii }}$ to keep their family life as they wished.

The first set of laws to control the morals of women in the kingdom of Choson and the basic issues of marriage was found in the Law of Governance of the Kingdom of Choson (Choson kyongguk chon [朝鮮經國典]) in 1394, which considered it important to control the morals of men, especially women, in order to achieve beautiful ceremonies and good governance. In practice, the main restrictions are imposed only on women, and restrictions on men in this regard - for example, polygamy, keeping concubines - are almost not taken seriously. According to a law adopted in 1406, the remarriage of a woman was defined as a gross violation of the code of ethics $[8,3-5 ; 5,210$ 218].

In 1432, a set of laws entitled "Illustrated Guide to the Three Commitments" [Samgang haengsil to - 삼강행실도 (三綱行實圖)]] was published [10;1-30]. In this book, the lives and actions of a hundred people who fall into three categories, such as a good generation, a wise husband, and a faithful wife, are revealed in various pictures, poems, and textual units. In 1481, the book The Establishment of the Three Obligations of Men with Illustrations of Wise Women [Samgang haengsil yollyo to - 삼강 행실열려도 (三綱行實烈女圖)] was published in hangil to help improve morality in both the capital and the provinces. Such books have given good results because they can be read by ordinary women as well (it was easier to study hangil and from the earliest times it was more common among women than men) $[4,10]$.

The Penal Code of 1461, which was later included in the Kyongguk taejon [a large set of rules (laws), 經國大典], stated that "if a woman belonging to a noble family behaves immorally, this action must be recorded." Such immoral acts included going to the birthplace without permission and entering the temple. The purpose of maintaining such records set out in the Kyongguk taejon set of laws was to give a legitimate view of the future treatment of the children of immoral women [11, 37-38]. That is, the children of such women are deprived of the right to hold public office. It is also defined as a violation of morality for a woman to marry two or three times. In the early Choson period, a "land for fidelity” [susinjon 수신전 (守信田)] was given to support widows and prevent remarriage. The aim was to provide for the widows and their children financially as their husbands did during their lifetime [7, 50-74]. The following record from Songjong Sillok shows that this type of land distribution played a key role in supporting the preservation of women's morals: "The land given for the preservation of fidelity was established to encourage women to remain honorable. This uniquely important institution plays an important role in the moral transformation of the people and the preservation of the correctness of customs" [8, 15-17]. After the death of her husband, 
women who remained faithful to him and dedicated their lives to their children were able to receive not only land but also various benefits from taxes.

\section{Divorces}

Confucianism takes a negative view of divorce. According to Confucianism, rulings are a manifestation of social disorder. However, it did not completely overturn the rulings. "Seven Reasons for Divorce" ("chilgo chiak" [칠고 지악]) meant more serious than simple reasons. The seven grounds are that a woman disobeys her parents, has no children, commits adultery, steals, is jealous, has a chronic illness, and talks too much. A man who saw any of the above in his wife was entitled to divorce his wife without any other serious reason. Of course, Confucianism cannot be blamed for the total discrimination against women: just as there were grounds for divorce, there were also three principles of sambugŏ, which were designed to keep women in marriage. But it does not have clear points like the seven bases, but is determined by the general condition of the divorcing couple. In 1413, a law was passed that allowed men to keep only one legal wife in their marriage at a time. Although the law abolished second wives, in practice men could keep concubines. But there was one positive side to this for the first wife: the children born to the concubines could not claim the inheritance. On the other hand, the situation of divorce among those who did not give birth to a son by his legal wife was serious [6, 140-144].

If a husband realizes that his wife has committed one of the "seven evils," including "disobedience to mothers-in-law, infertility, adultery, jealousy, hereditary disease, gossip, and theft", divorce leads to the execution of the woman in the worst cases. Even in the absence of an appropriate process or evidence, a man's word was capable of destroying a woman. However, the woman's condition remained deplorable even when divorce cases occurred without execution. The divorced woman was faced with two options: first, to spend the rest of her life in poverty, or to commit suicide. The second method was often applied to women belonging to the noble yangban family and to the ladies of the palace. The treatment of women whose husbands had died was also quite serious. Although the woman is not directly responsible for her husband's death, it is somewhat surprising that widows are looked down upon in society in a very low and divisive way. If a highranking woman decides to remarry, there is no objection, but as noted above, the sons of such a woman from a second marriage are deprived of a number of rights, including the right to work in the civil service and pass state exams. Even unmarried "older girls" were more respected than widows. In the eyes of members of Korean society at this time, she was not yet married, but older girls still had the opportunity to start a prestigious family. The widows had already taken advantage of such an opportunity. Also, in the Kingdom of Choson, the "Anti-Marriage Act" was officially declared in 1477, according to which if a woman remarried, her sons were restricted from holding public office; this law officially forbade women to marry for a second time, regardless of lineage [5, 208210]. In addition, widows will now be presented with a more 'sharpened' version of the previous two paths. To demonstrate the loyalty and devotion that Confucian teachings demanded of women, a widow had to drink either pedo (poison) or stab herself in the chest with a dagger. Whoever chooses one of these two and succeeds in doing so would be honored after her death and set an example to other women. King Seongjon sentenced a widow who was a member of the royal family to death in 1489 for living with a slave.

Thus, a system of obligations and duties aimed at maintaining the unity of the family was firmly established, a system was established in which the observance of all was strictly controlled, and violators were punished regardless of their position in the social stratum.

\section{Conclusion}


The period of monarchy and dynasty rule founded by $\mathrm{Yi}$ Song Ge shaped the culture and whole state order that has become a value in today's Korean republics and is ingrained in the mentality of the people. Although in medieval Korea the responsibility for the strength and unity of the family was largely the responsibility of the woman, the fact that men had significantly more privileges and rights was one of the distinctive features of patriarchal society. Some of these rights and privileges were in unwritten "value" status, which in itself led to gender inequality.

Of course, South Korea, as one of the most globalized countries to date, has created a legal framework to protect the rights and freedoms of women. This is evidenced by the fact that the family is taken care of by the state as a serious social institution, including the last Constitution of 29 September 1987 (Article 37), which establishes rules such as individual freedom and equality of the parties to the marriage.

\section{References:}

1. Ven. Phramaha Nopadol Saisuta. The Buddhist Core Values and Perspectives for Protection Challenges: Faith and Protection. (Deputy Dean, Faculty of Buddhism). Mahachulalongkorn Uniserity, Thailand. 2012.

2. Cawley, N. Kevin. Reinforced heteronormativity: gender constructs in Chosŏn ( 朝鮮 ) Korea. Irish Journal of Asian Studies, 4, 2018, pp. 39-52. https://irishjournalofasianstudies.files.word press.com/2018/12/IJAS4_Cawley-4.pdf (Accessed: 10 January 2019). http://hdl.handle.net/10468/7280;

Downloaded on 2020-04-17T15:19:13Z.

3. Hyaeweol Choi. Gender and Mission Encounters in Korea: New Women, Old Ways. Seoul-California Series in Korean Studies, 1; University of California Press. 2009.
4. Insook Han Park, Lee-Jay Cho. Confucianism and the Korean Family. Source: Journal of Comparative Family Studies, Vol. 26, No. 1, Families In Asia: Beliefs And Realities (Spring 1995), pp. 117-134. http://www.jstor.org/stable/41602370.

5. Kim, Jin Wung. A history of Korea: from "Land of the Morning Calm" to states in conflict /Indiana University Press, Bloomington, Indianapolis, USA, 2012.

6. Lee Sook-in. The Imjin War and the Official Discourse of Chastity. (Translated by Adam Bohnet, UBC). Seoul Journal of Korean Studies 22, no. 2 (December 2009): 137-156. Kyujanggak Institute for Korean Studies. 2009.

7. Lim, Sungyun. Rules of the House: Family Law and Domestic Disputes in Colonial Korea. University of California Press. 2019.

8. Martina Deuchler. 'The Tradition: Women during the Yi Dynasty.' Virtues in Conflict: Tradition and the Korean Woman Today. Seoul: Samhwa, 1997.

9. Policies toward Buddhism in Late Koryŏ and Early Joseon. In Buddhism in the Early Chosŏn: Suppression and Transformation, edited by Lewis R. Lancaster and Chai-shin Yu, 1-58. Berkeley: Institute of East Asian Studies. 1996.

10. Young Kyun Oh. Printing the Samgang haengsil-to 三 綱 行 實 圖 (Illustrated Guide to the Three Relationships), a Premodern Korean Moral Primer. School of International Letters and and Cultures, Arizona State University, Tempe, Arizona, USA youngoh@asu.edu. East Asian Publishing and Society 1, 2011.

11. 이남희. 조선 시대 족보와 여성의 지위. (Lee Nam Hui. Choson shide chokpova yeosonge chiui - "Genealogies of the Chosun Period and the Role of 
Women [in them]). 기록인, 2013

WINTER. Vol.25.

From my point of view, it would not be wrong to say that the Choson Kingdom, unlike many of its contemporaries, was one of the first to achieve the status of a secular state. For from that time onwards, an order was established in which the ruler was subject to the ruler, not to the religion.

\footnotetext{
${ }^{\mathrm{i}}$ A reformed version of Orthodox Confucianism in the 15 th century.

ii From my point of view, it would not be wrong to say that the Choson Kingdom, unlike many of its contemporaries, was one of the first to achieve the status of a secular state. From that time onwards an order was established in which religion was subject to the authority of the king.

iii Anban [안반] is the Korean word for "inner courtyard".
} 